\title{
A Comparison of Shoulder Stabilizer Muscle Activities of Therapeutic Climbing and Isometric Exercise in Patients with Shoulder Impingement Syndrome
}

\author{
Eun-Jung, Kim', Se-Hun, Kim² \\ 'Department of Physical Therapy, College of Health Science, Dongshin University, Naju; ${ }^{2}$ Department of Physical Therapy, Graduate School, Seonam \\ University
}

Purpose: The purpose of this study was to compare therapeutic climbing exercise and general isometric exercise in patients with shoulder impingement syndrome.

Methods: Among 20 adults, study subjects were arbitrarily classified into an experimental group of 10 and a control group of 10. The control group performed general isometric exercise (ISE) and the experimental group performed therapeutic climbing exercise (TC) (3 sets, 3 times per week for 8 weeks). To evaluate the effects of exercise, subjects were evaluated using a Disabilities of the arm, shoulder and hand score (DASH), a goniometer for range of motion, and shoulder activity measured serratus anterior, upper trapezius, and lower trapezius. Independent and paired t-test were used for comparison of the effect between groups.

Results: DASH scores showed a significant decrease in both groups after 8 weeks of treatment $(p<0.001)$ and significant difference was observed between the TC groups $(\mathrm{p}<0.01)$. Flexion and abduction were significantly increased after 8 weeks of treatment in the ISE group $(p<0.001)$ and flexion, abduction, external and internal rotation were significantly increased after 8 weeks of treatment in the TC group $(p<0.001)$. Serratus anterior and lower trapezius activity were significantly increased after 8 weeks of treatment $(p<0.001)$ and upper trapezius activity was not significantly increased after 8 weeks of treatment in the ISE group ( $p>0.05)$. Serratus anterior, lower trapezius, and upper trapezius activity were significantly increased after 8 weeks of treatment in the TC group $(p<0.001)$.

Conclusion: Scapular stabilizing exercise using a therapeutic climbing exercise increases range of motion and decreases DASH, and increases activity of shoulder muscles in patients with impingement syndrome.

Keywords: Therapeutic climbing, Shoulder muscle activity, DASH

\section{서 론}

견관절은 인체에서 가장 큰 범위의 운동이 가능하고 탈구와 아탈구 가 빈번히 일어나는 관절로써 만성 견관절 통증은 어깨부위의 통증 이나 관절가동범위 제한 또는 기능 장애와 같은 증상을 야기하는 대 표적인 근골격계 질환이다.1.2 만성 견관절 통증의 원인으로는 견봉하 충돌 증후군, 회전근개 파열, 동결견, 견봉활액낭염, 퇴행성 변화 등 많은 요인들이 있으며, 그 중 견봉하 충돌 증후군은 어깨 통증 환자 의 가장 일반적인 어깨통증 중 하나이다. ${ }^{3}$ 견봉하 충돌 증후군은 견 봉하 활액낭과 견봉 전하방으로 지나는 극상근의 건이 압박되어 기 계적 마모가 발생하는 것으로 회전근 건증, 상완 이두군 건증, 회선근

Received Mar 22, 2016 Revised Apr 18, 2016

Accepted Apr 19, 2016

Corresponding author Se-Hun, Kim

E-mail ptsehun@gmail.com
개 파열 등과 같은 염증과 퇴행성 변화를 일으켜 견관절의 기능 이상 과 통증을 발생시키며 삶의 질을 저하시키는 요인이 된다.,5

견관절 충돌증후군은 내적 원인과 외적 원인으로 나눌 수 있으며, 내적 요인으로는 견봉돌기 경사도, 견봉돌기나 상완골의 해부학적 기 형이나 부정유합, 오훼견봉 인대와 견쇄관절 비후 등이 있다.6.7 또한 이 러한 요인들은 회전근개 건내에서 염증 변화를 일으킬 수 있으며, 회 전근개 파열을 일으키는 주요 원인으로 작용한다고 보고되고 있다. ${ }^{4}$

외적 요인으로는 오훼견봉돌기 궁의 해부 기형과 회전근개 외부에 서 일어나는 힘과 관련이 있으며 회전근개와 견갑골 주변근의 불균 형, 자세변화, 운동 또는 직업적 영향으로 인한 과사용 등 이 있다. 어 깨 관절의 움직임은 상부승모근, 하부승모근, 전거근 등이 견갑골의 
상방회전을 만들어내기 위한 짝힘으로 조절되는데, 이 힘이 붕괴되 면 견관절의 운동역학적 변화를 가져오게 되며 견갑골의 비정상적 인 움직임을 만들게 되고 견봉하 공간이 좁아지게 되어 충돌증후군 을 일으키며 목과 머리의 근활성에도 영향을 미치게 된다.910 또한 견 관절 충돌 증후군은 견갑골의 상방회전과 후방경사의 관절 가동범 위와 근력이 부족으로 인해 발생하며, 이를 회복시키는 재활 운동프 로그램에서 견갑골의 위치를 안정화시키기 위해 전거근과 하승모근 이 중요한 요소로 작용한다.11,12

견관절 충돌증후군을 해결하기 위한 방법으로는 치료적 운동프 로그램의 적용이 많이 선호되어 왔으며, 그 운동방법으로는 이완운 동을 병행한 자가 신장운동, 벽밀기 운동, 머리 위로 팔 들어올리기 운동, 등척성 운동, 푸시-업 플러스 운동 등이 많이 사용되고 특히 견 관절을 안정화시키기 위해 닫힌사슬운동을 이용한 운동 프로그램 이 이용하는 경향이 많았다.13-15

유럽을 중심으로 인공 암벽의 클라이밍 동작을 응용한 치료적 클 라이밍은 수술 후 재활, 노인성 질환, 신경학적 질환 및 정신적 질환에 까지 적용범위가 확대되고 있다.16 Muehlbauer 등 ${ }^{17}$ 은 보존적 운동에 비해 클라이밍 운동이 근력 강화와 가동성 증진에 효과적이라고 보 고하고 있으며, 치료적 클라이밍 동작은 닫힌사슬운동을 주로 사용 하지만 열린사슬 동작과 혼합하여 사용할 수 있는 장점이 있다. 특히 환측을 고정하고 다른 사지의 움직임을 통해 더 높은 근활성를 유도 할 수 있으며 홀더(Holder)의 위치를 변화시켜 다양한 근사용을 유도 할수있다. ${ }^{34}$

치료적 클라이밍에 관한 연구들이 소아뿐만 아니라 노인성 질환 을 가진 환자들을 대상으로 한 치료적 프로그램에 관한 연구들도 보 고 되고 있지만 스포츠 클라이밍에 관한 많은 연구들이 주를 이루고 있어 치료적 근거에 대해서는 아직 부족한 실정이다.18.19 이에 본 연구 에서는 견관절 충돌증후군이 있는 환자를 대상으로 등척성 운동치 료와 닫힌 사슬 내에서 등척성 수축을 유도할 수 있도록 고안된 치료 적 클라이밍 동작을 적용하여 상지 기능과 관절가동범위, 견관절 주 변근육인 상부승모근, 하부승모근, 전거근의 근활성에 어떠한 영향 을 미치는지 비교하여 치료적 클라이밍 동작이 견갑골 안정성에 미 치는 효과를 보고자 한다.

\section{연구방법}

\section{1. 연구대상}

본 연구는 목포에 소재하는 $\mathrm{D}$ 병원에 내원한 견관절 충돌증후군 환 자 20명을 대상으로, 견관절 안정화 운동군과 치료적 클라이밍군에 각 10 명씩 무작위 배치법으로 나누어 실시하였다. 본 연구의 대상자 는 실험과 연구목적을 충분히 이해하였으며, 동의서에 서명한 환자
만을 대상으로 하였으며 동신대학교 임상시험심사위원회의 연구계 획서 승인을 받아 진행하였다. 환자군의 선정 대상 기준은 Neer 충돌 증후군검사와 Hawkins 충돌증후군 검사 시에 양성을 나타내거나 외 회전 외전 동작 시 통증이 있거나 깡통 비우기 검사 시 통증이 있는 자로 적어도 1 가지 이상을 만족하는 환자로 선정하였다. ${ }^{20}$

대상자로 선정 시 통증을 심하게 호소하는 환자, 압박 검사 시 견 갑상완 관절의 불안정이 있는 환자, 다양한 어깨 수술을 시술 받은 환 자, 경추와 관련된 증상이 있는 환자는 제외하였다.

\section{2. 실험방법}

1) 운동 프로그램

모든 연구 대상자들은 온습포 20 분, 전기치료 15 분, 그리고 초음파 5 분을 적용한 후 운동을 수행하였다. 등척성 운동군(isometric exercise group)은 전거근, 상부 승모근, 하부 승모근에 도수적 저항을 이용한 등척성 운동을 실시하였으며, 표면 근전도 검사 동안 최대 근 수축표 준화에서 가장 근활성도가 높게 측정된 자세로 실시하였고, 도수 저 항은 환자가 통증을 느끼지 않은 범위에서 점진적으로 증가하였다. ${ }^{21}$

치료적 클라이밍 운동군(therapeutic climbing group)은 Lazik ${ }^{22}$ 에 의 해 제시된 shoulder adduction, internal rotation, external rotation 동작 을 치료적 클라이밍 벽 위에 정적으로 선 상태에서 실시하였으며, 운 동범위는 운동 수행 중 통증을 느끼지 않은 범위에서 점진적으로 증 가하였다(Figure 1).

두 그룹 모두 각각 10 회를 1 세트로 총 3 세트, 1 일 1 회, 주 3 회, 총 8 주 간 실시하였으며 강한 부하의 운동을 적은 횟수(5-6회)의 반복과 짧 은 지속 시간(5-6초)으로 실시하였고, 운동 수행이 가능해지면 점진 적으로 유지 시간과 반복 횟수를 증가시켰다. 모든 운동은 통증이 없 는 범위 안에서 행해졌다.

\section{2) 측정도구}

(1) 상지 기능장애 평가(disabilities of the arm, shoulder and hand score, DASH)

상지 기능장애는 한국판 disabilities of the arm, shoulder and hand score (DASH)를 사용하여 평가하였으며, 장지를 하나의 기능적 단위로 간 주하고 상지의 주관적 상태를 판정하는 도구이다. DASH 설문지는 30 문항으로 구성되어 있으며 5점 척도로 100점 만점에서 점수가 높 을수록 더욱 심한 장애가 있음을 의미하며, 한국어판 DASH 설문지 의 Cronbach' $\alpha=0.94$ 로 높은 타당도와 신뢰도가 있는 검사이다.23

\section{(2) 관절가동범위 측정(range of motion)}

이 검사는 운동 전, 후 환자의 기능적 활동성을 검사하는 방법으로 환자가 능동적으로 각각의 동작을 수행할 때 통증이 유발되지 않는 

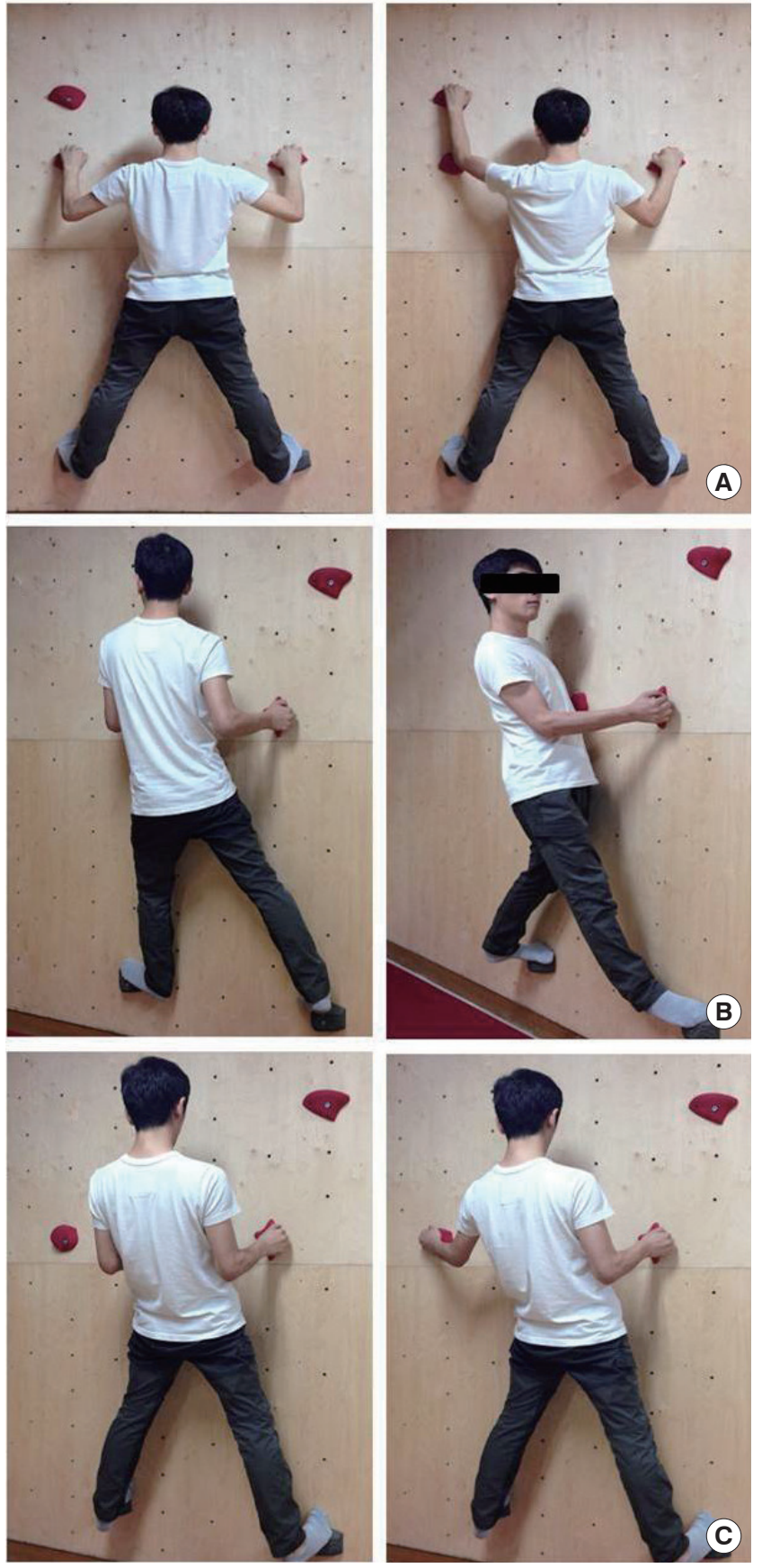

Figure 1. Therapeutic climbing program

범위에서 관절가동범위 마지막 지점을 $360^{\circ}$ 각도계(goniometer AP5159, 조은메디칼, 대한민국)를 이용하여 굴곡, 외전, 외회전, 내회 전을 각각 측정하였다.

\section{(3) 근 활성도 측정}

BTS suface EMG system (Bioengineering Inc., Italy)을 사용하여 전거근, 상부 승모근, 하부 승모근를 알아보기 위해 측정하였으며 표면 근전 도 신호에 대한 피부저항을 감소시키기 위해 부착 부위의 털을 제거
하고 사포를 2-4회 문질러 각질을 제거하고 소독용 알코올로 피부를 깨끗이 하였다.

표면 전극의 부착지점은 전거근은 견갑골 외측 하연과 흥곽 전 외 측에 위치한 근육 종지점 사이의 중앙 부위에 부착하였고, 상부 승모 근은 승모근 근복을 따라 견봉돌기 후부끝과 제7경추 극돌기 사이 중앙에서 약간 내측 부위, 하부 승모근은 제 8 흥추 극돌기와 견갑골 내측연과 견갑극과의 교차점 사이에 형성된 선을 따라 외측 상방 사 선방향에 부착하였다. 수집된 정보는 무선랜 통신 시스템(WIFI)을 통해 컴퓨터와 LAN 케이블로 연결된 무선공유기로 수신되어 POCKET EMG에서 사용되는 MYOLAB (software, BTS co, Italy)에서 원 데이터가 자동으로 표시된 값을 사용하였다.

측정은 12 초간 실시하며 처음 초와 마지막 1 초는 제외하고 10 초간 의 측청치 값을 사용하며, 총 3 회 측정하여 그 평균값을 이용하였다. 이때, 표준화 과정의 참고값은 도수의 저항을 준 상태의 최대 등척성 수축(maximal voluntary isometric contraction, MVIC) 시 각 근육의 최 대 근활성도를 5 초 동안 유지, 3 회 반복측정하였다. 5 초 동안의 자료 값을 RMS로 처리한 후 처음과 마지막 1 초를 제외한 3 초 동안의 평균 근전도 신호량을 $100 \% \mathrm{MVIC}$ 로 사용하였다. ${ }^{24}$

최대수의적 수축 측정 시 대상자는 편안히 선 자세에서 어깨 넓이 로 다리를 벌린 상태에서 손바닥이 앞을 향한 자세를 유지하고 동작 을 실시하였으며 수행 시 보상작용이 일어나지 않게 교육을 실시한 후 측정하였다. 동작은 각 근육별 움직임의 반대측으로 도수 저항을 준 상태에서 전거근은 견관절 90 도 외전 및 외회전 후 견갑골 상방회 전을 동반한 내전 동작을 실시하였고, 상부 승모근은 경부 후외측 신 전 후 견갑골을 거상, 하부 승모근은 견관절을 머리 위로 굴곡시킨상 태에서 견갑골을 하강시키는 동작을 실시하였다.25

\section{3. 통계 방법}

실험에서 얻어진 자료 값은 SPSS ver. 12.0 for Windows 통계 프로그램 (SPSS Inc., Chicago, IL, USA)을 이용하여 분석하였다. 모든 자료는 Shapiro-Wilk 검정 방법을 사용하여 정규 분포함을 확인하였다. 대상자들 의 일반적인 특성을 알아보기 위하여 기술통계방법을 사용하였다. 각 군간 의차이를 비교하기 위한 유의성 검정은 독립표본 $\mathrm{t}$ 검정(independent t-test)을 사용하였으며, 각 군 시기별 변화를 확인하기 위해 반복측 정분산분석(Repeated ANOVA)을 사용하였으며 사후검정은 Tukey's multiple range test를 실시하였으며 유의수준은 $\alpha=0.05$ 로 설정하였다.

\section{결 과}

\section{1. 연구대상자의 일반적인 특성}

본 연구에 참여한 대상자는 성인 남녀 20 명으로 등척성 운동군 남자 
5 명, 여자 5명이었으며, 치료적 클라이밍군은 남자 6명, 여자 4명이었 다(Table 1).

\section{2. 상지 기능장애 평가에 대한 각 군의 유의성 검정}

상지 기능장애 평가를 실시한 결과 두 군 모두 시기에 실험 전과 비교 하여 4 주차, 8 주차에서 유의한 감소를 보였으며 $(\mathrm{p}<0.001)$, 각 시기에 따 른 두 군 간의 차이에서는 운동 후 4 주차에서 유의한 차이를 보였으며 $(\mathrm{p}<0.05)$, 운동 후 8 주차에서도 유의한차이를 보였다 $(\mathrm{p}<0.01)$ (Table 2$)$.

\section{3. 관절 가동범위에 대한 각 군의 유의성 검정}

관절 가동범위에 대한 평가를 실시한 결과 등척성 운동군에서는 굴 곡, 외전 각도 측정 시 운동 전과 비교하여 운동 후 8 주차에서 유의한 차이가 나타났으며 $(\mathrm{p}<0.001)$, 외회전과 내회전 각도 측정 시 유의한 차이를 보이지 않았다. 치료적 클라이밍군에서는 굴곡, 외전, 외회전, 내회전 각도 측정 시 운동 전과 비교하여 8주차에서 모두 유의한 차 이가 나타났다 $(\mathrm{p}<0.001)$. 두 군의 운동 전, 후 변화량에서는 굴곡 각 도와 외전 각도에서 유의한 차이를 보였으며 $(\mathrm{p}<0.01)$, 외회전과 내회 전 각도에서 두 군의 변화량에서는 유의한 차이가 나타나지 않았다 ( $>$ >0.05) (Table 3).

\section{4. 근 활성도의 변화에 대한 각 군의 유의성 검정}

근 활성도 변화에 대한 평가를 실시한 결과 등척성 운동군에서는 전

Table 1. General characteristics of subjects

$(n=20)$

\begin{tabular}{lcc}
\hline & ISE Group $(\mathrm{n}=10)$ & TC Group $(\mathrm{n}=10)$ \\
\cline { 2 - 3 } & Mean \pm SD & Mean \pm SD \\
\hline Gender (M/F) & $5 / 5$ & $6 / 4$ \\
Age $(\mathrm{yr})$ & $54.0 \pm 4.1$ & $55.6 \pm 7.4$ \\
Height $(\mathrm{cm})$ & $163.6 \pm 6.3$ & $160.2 \pm 8.9$ \\
Weight $(\mathrm{kg})$ & $58.5 \pm 8.4$ & $61.8 \pm 7.7$ \\
\hline
\end{tabular}

Values are presented as mean \pm standard deviation.

ISE Group: Isometric exercise group, TC Group: Therapeutic climbing group.
거근에서 운동 전과 비교하여 운동 후 8주차에서 유의한 차이를 보 였으며(p<0.001), 하부 승모근에서 운동 전과 비교하여 운동 후 8 주 차에서 유의한 차이를 보였다 $(\mathrm{p}<0.01)$, 상부 승모근에서는 운동 전과 비교하여 유의한 차이가 나타나지 않았다( $p>0.05)$. 치료적 클라이밍 군에서는 전거근, 상부 승모근, 하부 승모군에서 운동 전과 비교하여 운동 후 8 주차에서 유의한 차이를 보였다 $(\mathrm{p}<0.001)$. 두 군의 운동 전, 후의 변화량에서는 전거근과 하부승모근에서만 유의한 차이를 보였 다 $(\mathrm{p}<0.05)($ Table 4$)$.

\section{고 찰}

견관절은 관절 운동이 가장 큰 부분으로 넓은 범위에서 자유롭게 움 직일 수 있지만 이로 이내 견관절 부위에 다양한 질환들이 발생하며, 일차 진료 내원 환자 1,000 명 당 $12-25$ 명이 견관절의 문제를 호소하는 임상에서 흔히 접하는 문제이다. ${ }^{26}$ 이를 해결하기 위한 많은 연구에서 는 견갑골의 움직임이 견관절의 손상에 매우 중요한 역할을 하고 있 기 때문에 견관절과 견갑골의 근육 운동을 강조하고 있다. ${ }^{14,27}$ 견관절 문제를 해결하기 위한 방법으로 최근 등척성 운동뿐만 아니라 유지 이완 기법을 이용한 운동과 닫힌사슬운동 등 많이 사용되고 있으며 특히 닫힌사슬운동은 견관절 전체에 직접적인 축성 압박으로 줄 수 있으며, 고유수용성감각의 촉진과 주변 근육의 협응 수축을 일으킬 수 있는 방법으로 널리 사용되고 있다.28,29

본 연구는 견관절 충돌 증후군 환자에게 등척성 운동군과 닫힌 사슬 기전을 이용한 치료적 클라이밍군을 적용하여 상지 기능장애 평가(DASH), 관절가동범위 $(\mathrm{ROM})$ 그리고 견갑골 주변근의 근활성 도를 측정하여 비교하였다.

상지 기능장애 평가에서는 운동 전, 후 등척성 운동군과 치료적 클라이밍군 모두에서 유의한 감소가 있었으며 두 군 간의 차이에서 는 운동 후 유의한 차이를 보였다. 위 결과는 스트레칭과 근력운동이 $\mathrm{DASH}$ 점수의 감소를 보인 Comargo 등 ${ }^{30}$ 의 연구에서 같은 결과를 보

Table 2. A comparison of disabilities of the arm, shoulder and hand score in each groups

(Unit: score)

\begin{tabular}{|c|c|c|c|c|c|c|}
\hline & Pre-test & 4 weeks & 8 weeks & (I)Period & (J)Period & $p$ \\
\hline \multirow[t]{3}{*}{ ISE } & $53.31 \pm 5.73$ & $45.54 \pm 6.12$ & $36.64 \pm 5.15$ & Pre test & 4 weeks & $0.000^{+++}$ \\
\hline & & & & & 8 weeks & $0.000^{+++}$ \\
\hline & & & & 4 weeks & 8 weeks & $0.018^{+}$ \\
\hline \multirow[t]{3}{*}{$\mathrm{TC}$} & $54.76 \pm 7.12$ & $43.86 \pm 5.89$ & $31.73 \pm 6.32$ & Pre test & 4 weeks & $0.000^{+++}$ \\
\hline & & & & & 8 weeks & $0.000^{+++}$ \\
\hline & & & & 4 weeks & 8 weeks & $0.006^{++}$ \\
\hline $\mathrm{p}$ & 0.846 & $0.039^{*}$ & $0.007^{\star \star}$ & & & \\
\hline
\end{tabular}

Values are presented as mean \pm standard deviation.

Tested by independent t-test IE-TC ${ }^{*} \mathrm{p}<0.05,{ }^{* *} \mathrm{p}<0.01,{ }^{* * *} \mathrm{p}<0.001$.

Significance was tested by repeated measure ANOVA within each group.

Tukey's multiple range test within each group ${ }^{+} p<0.05,{ }^{++} p<0.01,{ }^{+++} p<0.001$.

ISE: Isometric exercise group, TC: Therapeutic climbing group. 
Table 3. A comparison of range of motion in each groups

(Unit: degree)

\begin{tabular}{|c|c|c|c|c|c|c|c|}
\hline & & $\operatorname{Pre}(\mathrm{A})$ & 8 weeks(B) & $(B-A)$ & (I)Period & (J)Period & $\mathrm{p}$ \\
\hline \multirow[t]{7}{*}{ Flexion } & ISE & $142.43 \pm 11.43$ & $150.63 \pm 13.44$ & $8.20 \pm 2.01$ & Pre test & 4 weeks & $0.000^{+++}$ \\
\hline & & & & & & 8 weeks & $0.000^{+++}$ \\
\hline & & & & & 4 weeks & 8 weeks & $0.007^{++}$ \\
\hline & $\mathrm{TC}$ & $137.81 \pm 12.76$ & $152.67 \pm 11.56$ & $14.86 \pm 1.20$ & & 4 weeks & $0.000^{+++}$ \\
\hline & & & & & & 8 weeks & $0.000^{t++}$ \\
\hline & & & & & 4 weeks & 8 weeks & $0.002^{++}$ \\
\hline & $\mathrm{p}$ & & & $0.004 * *$ & & & \\
\hline \multirow[t]{7}{*}{ Abduction } & ISE & $95.15 \pm 12.63$ & $101.84 \pm 11.74$ & $6.69 \pm 0.89$ & Pre test & 4 weeks & $0.004^{++}$ \\
\hline & & & & & & 8 weeks & $0.000^{+++}$ \\
\hline & & & & & 4 weeks & 8 weeks & $0.013^{+}$ \\
\hline & $\mathrm{TC}$ & $92.65 \pm 10.75$ & $105.51 \pm 10.18$ & $12.86 \pm 0.57$ & Pre test & 4 weeks & $0.000^{+++}$ \\
\hline & & & & & & 8 weeks & $0.000^{t++}$ \\
\hline & & & & & 4 weeks & 8 weeks & $0.006^{++}$ \\
\hline & $\mathrm{p}$ & & & $0.008 * *$ & & & \\
\hline \multirow[t]{7}{*}{ External rotation } & ISE & $50.10 \pm 15.38$ & $53.16 \pm 14.74$ & $3.06 \pm 0.64$ & Pre test & 4 weeks & 0.065 \\
\hline & & & & & & 8 weeks & $0.047^{+}$ \\
\hline & & & & & 4 weeks & 8 weeks & 0.793 \\
\hline & TC & $47.14 \pm 13.12$ & $52.75 \pm 14.75$ & $5.61 \pm 1.63$ & Pre test & 4 weeks & $0.011^{+}$ \\
\hline & & & & & & 8 weeks & $0.000^{+++}$ \\
\hline & & & & & 4 weeks & 8 weeks & 0.461 \\
\hline & $\mathrm{p}$ & & & 0.370 & & & \\
\hline \multirow[t]{7}{*}{ Internal rotation } & ISE & $22.68 \pm 17.73$ & $25.73 \pm 15.23$ & $3.07 \pm 2.50$ & Pre test & 4 weeks & 0.365 \\
\hline & & & & & & 8 weeks & $0.043^{+}$ \\
\hline & & & & & 4 weeks & 8 weeks & 0.142 \\
\hline & TC & $21.53 \pm 14.31$ & $26.83 \pm 14.24$ & $5.30 \pm 0.07$ & Pre test & 4 weeks & $0.034^{+}$ \\
\hline & & & & & & 8 weeks & $0.000^{t++}$ \\
\hline & & & & & 4 weeks & 8 weeks & 0.052 \\
\hline & $\mathrm{p}$ & & & 0.274 & & & \\
\hline
\end{tabular}

Values are presented as mean \pm standard deviation.

Tested by independent t-test IE-TC ${ }^{*} \mathrm{p}<0.05,{ }^{* *} \mathrm{p}<0.01,{ }^{* * *} \mathrm{p}<0.001$.

Significance was tested by repeated measure ANOVA within each group.

Tukey's multiple range test within each group ${ }^{+} p<0.05,{ }^{++} p<0.01,{ }^{+++} p<0.001$.

ISE: Isometric exercise group, TC: Therapeutic climbing group.

였으며, 점진적 근력운동를 통해 견봉하 충돌증후군 환자의 $\mathrm{DASH}$ 점수의 감소를 보인 연구와도 같은 결과를 보였다. DASH 점수는 상 지의 통증, 근력 약화, 뻣뻣함을 평가함과 동시에 기능적인 움직임, 실 생활에서 동작 수행 능력을 평가하는 항목들로 구성되어 있으며, Grant 등 ${ }^{31}$ 의 연구에서 치료적 클라이밍 동작은 등척성 운동을 통해 정적인 안정성뿐 아니라 동적인 움직임까지도 효과적으로 만들어 낼 수 있다고 보고하였다.

관절가동범위 평가에서는 견관절 굴곡과 외전에서 등척성 운동 군과 치료적 클라이밍군 모두 운동 전에 비해 유의한 증가를 보였다. 치료적 클라이밍 군은 외회전, 내회전에서도 운동 전에 비해 유의하 게 증가하였으나, 두 군의 가동범위의 변화량을 비교한 결과 굴곡과 외전에서만 유의한 차이를 보였다. 등척성 운동군은 근력 강화의 목 적으로 사용되어 가동범위의 변화에 많은 향상을 보이지 않았지만, Cools 등 ${ }^{1}$ 의 연구와 $\mathrm{Choi}^{32}$ 연구에서 견관절 충돌 증후군 환자에게
닫힌 사슬에서 안정화 운동이 가동범위에 더 효과적이라고 하였으 며, 치료적 클라이밍 운동은 닫힌 사슬의 운동 형태로써 이와 같은 결과를 보인 것으로 생각된다.

근 활성도 변화에 대한 평가를 실시한 결과 등척성 운동군에서는 전거근과 하부 승모근에서 운동 후에 유의한 변화를 보였으며, 상부 승모근에서는 운동 전과 비교하여 유의한 차이가 나타나지 않았다. 치료적 클라이밍군에서는 전거근, 상부 승모근, 하부 승모군에서 운 동 전과 비교하여 두 군의 운동 전, 후의 변화량에서는 전거근과 하 부 승모근에서만 유의한 차이를 보였다. Khosro과 $\operatorname{Simin}^{33}$ 의 닫힌사 슬운동이 어깨 근육의 안정화에 미치는 효과를 알아본 연구에서 닫 힌사슬운동 후 안정성에 관여하는 근육의 활성도 비가 증가되었다 는 연구와 일치하였다. Ludewig 등 15 은 정상인에게 닫힌사슬운동이 전거근과 상승모근의 $\mathrm{EMG}$ 측정 결과 전거근과 상승모근의 균형이 중요하다고 보고하였다. 또한 견관절의 움직임에서 전거근과 하부 승 
Table 4. A comparison of muscle activity in each groups

(Unit: \%MVIC)

\begin{tabular}{|c|c|c|c|c|c|c|c|}
\hline & & $\operatorname{Pre}(\mathrm{A})$ & 8 weeks(B) & $(B-A)$ & (I)Period & (J)Period & $p$ \\
\hline \multirow[t]{7}{*}{ Serratus anterior } & ISE & $15.53 \pm 10.64$ & $20.64 \pm 8.34$ & $5.11 \pm 2.30$ & Pre test & 4 weeks & $0.008^{++}$ \\
\hline & & & & & & 8 weeks & $0.000^{+++}$ \\
\hline & & & & & 4 weeks & 8 weeks & $0.035^{+}$ \\
\hline & TC & $14.67 \pm 9.15$ & $23.58 \pm 10.23$ & $8.91 \pm 1.08$ & Pre test & 4 weeks & $0.000^{+++}$ \\
\hline & & & & & & 8 weeks & $0.000^{+++}$ \\
\hline & & & & & 4 weeks & 8 weeks & $0.005^{++}$ \\
\hline & $p$ & & & $0.046^{*}$ & & & \\
\hline \multirow[t]{7}{*}{ Upper trapezius } & ISE & $21.65 \pm 13.74$ & $24.15 \pm 12.49$ & $2.50 \pm 1.25$ & Pre test & 4 weeks & 0.078 \\
\hline & & & & & & 8 weeks & 0.060 \\
\hline & & & & & 4 weeks & 8 weeks & 0.184 \\
\hline & TC & $20.23 \pm 11.75$ & $24.71 \pm 10.33$ & $4.48 \pm 1.42$ & Pre test & 4 weeks & $0.003^{++}$ \\
\hline & & & & & & 8 weeks & $0.000^{+++}$ \\
\hline & & & & & 4 weeks & 8 weeks & 0.297 \\
\hline & $\mathrm{p}$ & & & 0.182 & & & \\
\hline \multirow[t]{7}{*}{ Lower trapezius } & ISE & $16.59 \pm 7.63$ & $21.11 \pm 6.32$ & & Pre test & 4 weeks & $0.030^{++}$ \\
\hline & & & & & & 8 weeks & $0.003^{++}$ \\
\hline & & & & & 4 weeks & 8 weeks & 0.071 \\
\hline & TC & $14.71 \pm 8.11$ & $22.64 \pm 8.53$ & & Pre test & 4 weeks & $0.002^{++}$ \\
\hline & & & & & & 8 weeks & $0.000^{+++}$ \\
\hline & & & & & 4 weeks & 8 weeks & 0.083 \\
\hline & $\mathrm{p}$ & & & $0.025^{\star}$ & & & \\
\hline
\end{tabular}

Values are presented as mean \pm standard deviation.

Tested by independent $\mathrm{t}$-test IE-TC ${ }^{*} \mathrm{p}<0.05,{ }^{{ }^{* *}} \mathrm{p}<0.01,{ }^{* * *} \mathrm{p}<0.001$.

Significance was tested by repeated measure ANOVA within each group.

Tukey's multiple range test within each group ${ }^{+} p<0.05,{ }^{++} p<0.01,{ }^{++} p<0.001$.

ISE: Isometric exercise group, TC: Therapeutic climbing group.

모근의 적절한 활성화가 중요한 요인으로 작용하게 되고 상부 승모근 의 과도한 활성화는 전거근과 하부 승모근의 능력을 감소시키기 때 문에 견부 통증을 일으킬 수 있다고 하였다. ${ }^{1}$ Mally 등 ${ }^{34}$ 의 연구에서 는 치료적 클라이밍 동작이 각 분절의 근활성도 증가에 효과적이라 고 보고하였으며, 체간의 안정화를 위해 동측 상지와 반대측 하지를 교차 활성화시킨다고 하였다. 또한 Muehlbauer 등 35 연구에서는 클라 이밍 벽에서 홀더를 잡는 위치에 따라 어깨의 근활성도 변화를 알아 본 결과 어깨의 높이보다 높은 위치를 잡고 유지하는 것보다 평행한 위치의 홀더를 잡은 것이 어깨 근육의 활성도가 더 높게 나타났다고 하였으며, 이를 이용하여 치료적 클라이밍 운동 중 어깨의 근육의 근 활성도 향상을 효과적으로 조절할 수 있다고 보고하였다. 본 연구에 서 통증이 없는 범위 내에서 도수 저항보다 본인의 체중을 이용하여 근력 강화와 자세를 유지하기 위해 견갑대의 조절을 통한 안정성을 확보한 상태에서 운동이 이루어져 치료적 클라이밍군에서 유의한 변화량을 보인 것으로 생각된다.

본 연구의 제한점은 모든 변수에서 긍정적인 차이가 나타났지만 운동 수행 시 퇴행된 견관절의 과도한 긴장과 압력을 조절하기 어려 웠다는 점과, 대상자 수가 적었으며 특정 근육만을 대상으로 하였으
며, 견관절을 움직이는 근육들이 동원 순서에 대한 평가가 실시되어 있지 않아 그 효과를 일반화하는 데 어려움이 있었다. 또한 대상자의 일상생활에서 발생하는 견관절의 부하를 조절하지 못하였다. 본 연 구를 통해 견관절 충돌증후군 환자의 견관절 안정화 운동으로 치료 적 클라이밍 운동이 견관절 주변 근육의 근활성도를 증가시키고 이 를 통해 견갑골의 안정화를 높인다는 것을 알 수 있었다. 따라서 차후 에서 다양한 견관절 안정근에 대한 근 활성도에 관한 연구와 치료적 클라이밍을 통한 상, 하지의 협응력에 관한 연구가 계속되어야 할 것 이다.

\section{REFERENCES}

1. Good CR, MacGillivray JD. Traumatic shoulder dislocation in the adolescent athlete: Advances in surgical treatment. Current opinion in pediatrics. 2005;17(1):25-9.

2. Cools AM, Dewitte V, Lanszweert F et al. Rehabilitation of scapular muscle balance: which exercises to prescribe? Am J Sports Med. 2007; 35(10):1744-51.

3. Michener LA, McClure PW, Karduna AR. Anatomical and biomechanical mechanisms of subacromial impingment syndrome. Clin Biomech. 
2003;18(5):369-79.

4. Neer CS. Anterior acrimioplasty for the chronic impingement syndrome in the shoulder. A preliminary report. Journal Bone Joint Surgery Am. 1972;54(1):41-50.

5. McClure PW, Bialker J, Neff N et al. Shoulder function and 3-D kinematics in people with shoulder impingement syndrome before and after a 6-week exercise program. Phys Ther. 2004; 84(9):822-48.

6. Frieman BG, Albert TJ, Fenlin JM Jr. Rotator cuff disease: A review of diagnosis pathophysiology, and current trends in treatment. Arch Phys Med Rehabil. 1994;75(5):604-9.

7. Rathbun JB, Macnab I. The Microvascular pattern of the rotator cuff. J Bone Joint Surg Br. 1970;52(3):540-53.

8. Greenfield B, Catlin PA, Coats PW. Posture in patients with shoulder overuse injuries and healthy individuals. J Orthop Sports Phys Ther. 1995;21(5):287-95.

9. Bae SS, Kim BJ, Lee KH. A study of muscle imbalance of head, cervical and shoulder region. J Kor Phys Ther. 2001;13(3):769-76.

10. Bae SS, Choi JW, Chung HA et al. Biomechanical analysis of scapular pattern in proprioceptive neuromuscular facilitation. J Kor Phys Ther. 1999;11(3):65-9.

11. McClure PW, Michener LA, Karduna AR. Shoulder function and 3-dimensional scapular kinematics in people with and without shoulder impingement syndrome. Phys Ther. 2006;86(8):1075-90.

12. Brindle T, Nyland JA, Nitz AJ et al. Scapulothoracic latent muscle reaction timing comparison between trained overhead throwers and untrained control subjects. Scand J Med Sci Sports. 2007;17(3):252-9.

13. Han KJ, Choi BK. Comparison of the surface electromyographic signal of progressive resistance increase and progressive resistance decrease exercise. J Kor Phys Ther. 2008;20(1):11-6.

14. Seo BD, Shin HS. The effect of self stretching exercise in patients with shoulder adhesive capsulitis. J Kor Phys Ther. 2010;22(1):19-26.

15. Ludewig PM, Hoff MS, Osowski EE et al. Relative balance of serratus anterior and upper trapezius muscle activity during push-up exercises. Am J Sports Med. 2004;32(2):484-93.

16. Kohl B. Therapeutisches klettern untersuchung der auswirkungen eines klettertrainings an personen mit rückenschmerzen", unveröffentliche diplomarbeit an der leopold - franzensuniversität Innsbruck. Psychologie und Sportwissenschaften. 2005.

17. Muehlbauer T, Stuerchler M, Granacher U. Effects of Climbing on Core Strength and Mobility in Adults. Int J Sports Med. 2012;33(6):445-51.

18. Fuss F, Niegl G. Finger load distribution in different types of climbing grips, Sports Technology. 2012;5(3-4):151-5.

19. Russell SD, Zirker CA, Blemker SS. Computer models offer new insights into the mechanics of rock climbing. Sports Technology. 2012;5(34):120-31.
20. Roy JS, Moffet H, McFadyen BJ et al. Impact of movement training on upper limb motor strategies in persons with shoulder impingement syndrome. Sports Med Arthrosc Rehabil TherTechnol. 2009;1(1):8.

21. Jang KH, Choi JD, Lee MH et al. A comparison of modified sling exercise and general isometric exercise in patients with shoulder impingement Syndrome. J Kor Phys Ther. 2010;22(5):9-16.

22. Dieter Lazik. therapeutisches klettern. Thieme Georg Verlag, 2007.

23. Lim. JY, Song JH, Lee HY et al. Evalution of the reliability, construct validity, and responsiveness of the korean version of the DASH. J Korean Soc Surg Hand. 2005;10(4):192-8

24. Soderberg GL, Knutson LM. A guide for use and interpretation of kinesiologicelectromyographic data. Phys Ther. 2000;80(5):485-98.

25. Cram JR, Kasman GS, Holtz J. Introduction to Surface Electromyography. Maryland, Aspen. 1998.

26. Reilingh ML, Kuijpers T, Tanja-Harfterkamp AM et al. Course and prognosis of shoulder symptoms in general practice. Rheumatology. 2008;47(5):724-30.

27. Voight ML, Thomson BC. The role of the scapula in the rehabilitation of shoulder injuries. J Athl Train. 2000;35:365-72.

28. Lim WS, Shin HS, Kim IS et al. The effects of scapular pattern and holdrelax technique of PNF on the ROM an VAS in frozen shoulder patients. J Kor Phys Ther. 2002;14(1):15-26.

29. Kim SM, LEE HO, Bae SS. Effects on frozen shoulder as seen in the comparison hold-relax technique and ROM exercise. J Kor Phys Ther. 1995;7(1):51-9.

30. Camargo PR, Alburquerque-Sendín F, Avila MA et al. Effects of Stretching and Strengthening Exercises, With and Without Manual Therapy, on Scapular Kinematics, Function, and Pain in Individuals With Shoulder Impingement: A Randomized Controlled Trial. J Orthop Sports Phys Ther. 2015;45(12):984-97.

31. Grant S, Hasler T, Davies C et al. A comparison of the anthropometric, strength, endurance and flexibility characteristics of female elite and recreational climbers and non-climbers. J Sports Sci. 2001;19(7):499-505.

32. Chio JD. Effect of 7-week serratus anterior strengthening exercises on shoulder pain with serratus anterior weakness. Yonsei University. Dissertation of Doctorate Degree. 2008.

33. Khosro khademi kalantari, Simin Berenji Ardestani. The effect of base of support stability on shoulder muscle activity during closed kinematic chain exercises. J of Bodywork and Movement Therapies. 2014;18(2): 233-8.

34. Mally F, Litzenberger S, Sabo A. Surface electromyography measurements of dorsal muscle cross-activation in therapeutic climbing. Procedia Engineering. 2013;60:22-27.

35. Muehlbauer, T. Granacher, U. Jockel B et al. Muscle Activation during Therapeutic Climbing Exercises. Sportverl Sportschad. 2013;27:162-8. 